\title{
Результати стентування хворих на рак верхніх та середніх відділів стравоходу
}

\author{
Національний інститут раку, Київ \\ Одержано 10.06.2019 \\ Прийнято до друку 05.07.2019 \\ DOI: 10.32471/clinicaloncology.2663-466X.38.22537
}

\begin{abstract}
Актуальність. На момент встановлення діагнозу хворі на рак стравоходу (РС) найчастіше $є$ неоперабельними у зв'язку із занедбаністю процесу. Тривалість життя в інкурабельних пацієнтів з вираженою дисфагією становить в середньому 90 днів. Радикальне лікування може бути виконано лише у 20-30\% хворих з 5-річною виживаністю у межах 10,3-35\%. Мета. Дослідити безпосередні та віддалені результати стентування хворих на РС залежно від локалізації первинної пухлини. Об'єкт і методи. Проаналізовано досвід використання внутрішньостравохідних саморозширюваних стентів у хворих на РС (49 випадків - рак верхніх і 73 - середніх відділів стравоходу) в порівнянні з накладенням стоми (53 випадки). Результати. В результаті лікування у всіх хворих, які були стентовані, зменшувалася дисфагія, з'являлася можливість приймати їжу звичайним шляхом, поліпшувалася якість життя, у багатьох з'являлася можливість продовжити терапію. Виявлено, що стентування неоперабельних хворих на рак верхніх і середніх відділів стравоходу є виправданим, воно дозволяє пацієнтам продовжити харчуватися природним шляхом і тим самим значно покращує якість життя, на відміну від накладення стоми. Хворі на рак верхніх відділів стравоходу, які були стентовані не з приводу нориць, мали достовірно кращі віддалені результати виживаності, ніж хворі на РС після накладення стоми і подібні хворі на рак середніх відділів стравоходу, причому виживаність хворих на рак верхніх відділів стравоходу після стентування не з приводу нориць була значно кращою, ніж при їх наявності. Хворі на рак середніх відділів стравоходу, які були стентовані з приводу нориць, мали такі ж віддалені результати виживаності, як і хворі на рак середніх відділів стравоходу, які були стентовані не з приводу нориць, що свідчить про високу ефективність стентування при раку середніх відділів стравоходу з приводу нориць. Висновки. Стентування неоперабельних хворих на рак верхніх та середніх відділів стравоходу $є$ виправданим, воно дозволяє пацієнтам продовжити харчування природним шляхом та тим самим значно покращує якість життя, на відміну від накладення стоми.
\end{abstract}

Ключові слова: рак стравоходу; рак верхніх відділів стравоходу; рак середньої частки внутрішньогрудного відділу стравоходу; стент; стома; нориця.

\section{ВСТУП}

На момент встановлення діагнозу хворі на рак стравоходу (РС) найчастіше є неоперабельними у зв’язку із занедбаністю процесу. Тривалість життя інкурабельних пацієнтів з вираженоюдисфагією становить в середньому 90 днів [1]. Радикальне лікування може бути виконано лише у $20-30 \%$ хворих з 5-річною виживаністю у межах 10,3-35\% [2-6]. Хворим із занедбаними процесами при резектабельній первинній пухлині досить часто виконують паліативні резекції та екстирпації стравоходу, які забезпечують тимчасове усунення симптомів. Але при виникненні рецидиву пухлини в зоні анастомозу або втиснення метастатичним процесом зовні з'являються ті самі проблеми. При нерезектабельності пухлини класично накладається нутритивна гастростома для харчування, яка не забезпечує пацієнту можливості нормального ковтання та $є$ важким психологічним фактором для нього. Шунтуючі операції, безумовно, дозволяють приймати їжу перорально, але вони є високотравматичними, як і інші втручання на стравоході, а ризик післяопераційних ускладнень після них досить високий. Незадовільну ефективність мають і численні методики симптоматичного усунення дисфагії, особливо при РС: бужування, балонна дилатація, електро- та лазерна коагуляція, встановлення жорстких внутрішньостравохідних протезів. Крім цього, беручи до уваги несприятливий прогноз захворювання, коротку тривалість життя, $€$ сенс звернути увагу на менш інвазійні операційні технології, до яких наразі належить стентування саморозширюваними ендопротезами. Це дозволяє вирішити основні завдання - усунути дисфагію, підвищити якість і збільшити тривалість життя пацієнтів, провести паліативне лікування.

Окрім проблеми дисфагії та, як наслідок, кахексії, дуже часто у хворих на РС виникає грізне ускладнення РС - стравохідні нориці, якіє високопотенційним летальним ускладненням. Вони найчастіше виникають при розпаді місцево-поширених злоякісних пухлин стравоходу, трахеї, бронхів, легень, первинних або метастатичних пухлин середостіння; рідше - при інших захворюваннях, наприклад туберкульозі, стресовій виразці стравоходу. Причинами ятрогенних нориць можуть бути інструментальні пошкодження органа (езофагоскопом, шлунковим зондом, ендотрахеальною наркозною трубкою, бужом, кардіодилататором), травми стравоходу під час хірургічних операцій на суміжних органах, тривала інтубація трахеї (пролежні). До ятрогенних можна також віднести нориці, що розвиваються при неспроможності стравохідних анастомозів, а також післяпроменеві [7].

3 огляду на вищенаведене стенти мають суттєві переваги, а саме: можливість встановлення навіть при дуже виражених звуженнях, постійне розширення звуженої ділянки стравоходу, низьку ймовірність їх закупорки їжею та здатність герметизувати просвіт стравоходу за рахунок покриття стента біологічно інертною плівкою. Усі ці якості роблять саморозширювані стенти незамінними як для усунення дисфагії, так і для лікування стравохідних нориць. До недоліків стентів належать можливість їх зміщення в момент встановлення, обтурація пухлинними розростаннями по краях, здатність ковзання в дистальному напрямку в міру обростання колагеном, важкість видалення або передислокації, а також висока вартість.

У світовій літературі описано кілька можливих способів встановлення стентів за допомогою ендоскопічної техніки: під рентгенологічним контролем, який вважають кращим більшість дослідників [8-11], під візуальним контролем [12-16], під подвійним - ендоскопічним і рентгенологічним - контролем [17]. Деякі автори встановлюють стенти при ураженнях цих локалізацій без використання ендоскопів - тільки під рентгенологічним контролем, орієнтуючись лише на відстань від різців до верхнього краю пухлини, певну при ендоскопічному дослідженні [18]. Спосіб введення стента залежить від уподобань і досвіду дослідника, а також від традицій і можливостей клініки. Однак ці переваги повинні бути засновані на об'єктивних критеріях. 
Мета роботи: дослідити безпосередні та віддалені результати стентування хворих на РС залежно від локалізації первинної пухлини.

\section{ОБ'ЄКТ І МЕТОДИ ДОСЛІДЖЕННЯ}

В основну дослідну групу увійшли 49 хворих на рак верхніх відділів стравоходу (РВВС), яким були встановлені внутрішньостравохідні стенти. Чоловіків було 45 (91,84\%), жінок - 4 (8,16\%). Вік хворих коливався від 40 до 78 років, середній вікстановив 59,9 року. Плоскоклітинний РС був підтверджений у 47(95,92\%) хворих, у $2(4,08 \%)$ пацієнтів був діагностований недиференційований рак.

Важливим є вивчення структури показань до проведення стентування у цих хворих. 15 первинним пацієнтам стенти було встановлено до проведення спеціального лікування, причому у 10 хворих показаннями до стентування була дисфагія IIIIV ступеня, кахексія, загальний стан хворого. 5 хворим стентування було виконане з приводу стравохідних нориць. У 28 хворих стенти встановлено після проведення спеціальної терапії на тлі посилення синдрому дисфагії. Із них 5 хворих були стентовані після променевої терапії (ПТ), 7 - після поліхіміотерапії (ПХТ; селективна ПХТ проводилася у 5 випадках, системна ПХТ - у 2), 16 - після радіохіміотерапії (РХТ; селективна ПХТ проводилася у 14 випадках, системна ПХТ - у 2). У 6 хворих стентування було виконане з приводу стравохідних нориць, що розвинулися під час лікування, - у 4 випадках після РХТ (в них застосована селективна ПХТ) та у 2 - після ПХТ ( 1 - системної та 1 - селективної).

У порівняльну групу увійшли 73 хворих на рак середньої частки внутрішньогрудного відділу стравоходу (РСЧВВС), яким також було виконане стентування. Чоловіків було $69(94,52 \%)$, жінок - 4 (5,48\%), вік коливався від 20 до 82 років, середній вік становив 58,9 року.

У 39 хворих стент встановлено відразу після обстеження та госпіталізації у відділення у зв'язку з дисфагією високого ступеня (24 хворих) та наявністю стравохідних нориць (15 хворих). У 28 хворих виконано стентування після проведення спеціальної терапії у зв'язку зі стійкою дисфагією, що розвинулася на тлі лікування. Із них після ПТ стент встановлено 16 хворим, після ПХТ - 4 (системна ПХТ - 1 випадок, селективна - 3), після РХТ - 8 (системна ПХТ застосована у 5, селективна - у 3 пацієнтів). У 6 хворих після проведення лікування стентування було виконане у зв'язку з виникненням стравохідної нориці на тлі лікування (4 - після ПТ, 2 - після РХТ із застосуванням селективної ПХТ).

У контрольну порівняльну групу увійшли 53 хворих на РС, яким було виконане накладення стоми з приводу дисфагії та конкуруючої супутньої патології. Чоловіків було 44 (83,02\%), жінок -9 (16,98\%). Вік хворих коливався від 38 до 74 років, середній вік - 59,7 року. За локалізацією первинної пухлини у стравоході хворих на РВВС було $22(41,51 \%)$, РСЧВВС 18 (33,96\%), рак нижніх відділів стравоходу - 13 (24,53\%).

Слід зазначити, що в усі групи дослідження були включені хворі, у яких не планувалося виконання радикального оперативного втручання, а саме хворі з неоперабельним та ускладненим РС та вираженою супутньою патологією, що не дозволяла розглядати пацієнтів як кандидатів на радикальне лікування. Тому вивчення розподілу хворих за TNM нам здалося недоцільним. Також завданням було дослідити результати лікування хворих на тлі стентування, однак вивчення структури ускладнень не ставилося за мету.

Методика встановлення саморозиирюваних внутріиньостравоxiдних стентів. Незважаючи на те що деякі автори використовують ендоскопічний метод установки стравохідних стентів, вже в ході перших спроб стентування ми переконалися в низькій ефективності такого підходу. Тому в основної частини пацієнтів стентування ми проводили під прямим рентгеноскопічним контролем. Установка стентів під рентгенологічним контролем була двох видів: 1) основний спосіб - введення стента одночасно з доставковим пристроєм; 2) допоміжний спосіб - введення доставкового пристрою, що містить не стент, а буж, з подальшим його вилученням і введенням стента в доставковий пристрій через ротовий кінець останнього. Перший спосіб застосовували при достатньо широкому і прямому просвіті звуженої ділянки, другий - при більш вузьких (діаметром менше 3-4 мм) і звивистих каналах. Ефективність стентування була істотно підвищена завдяки удосконаленню нами доставкового пристрою (Патент України на корисну модель № a 26567 від 25.09.2007 р.), що дозволило проводити доставковий пристрій, використовуючи ангіографічний провідник-струну.

Перед процедурою стентування хворим проводили премедикацію, яка полягала в підшкірному введенні розчинів алкалоїдів опію та атропіну. Для визначення рівнів початку і закінчення звуження стравоходу або для візуалізації нориці пацієнти приймали рідку рентгеноконтрастну суспензію. Ці ключові орієнтири відмічали на шкірі передньої грудної стінки рентгеноконтрастними мітками. Потім через рот в стравохід вводили ангіографічний катетер з провідником-струною типу «Ј» і під рентгенологічним контролем проводили його через звужену ділянку стравоходу в шлунок, після чого катетер витягували, залишаючи в стравоході струну. При вузьких і звивистих звуженнях проведення провідника вимагало певних маневрів і, відповідно, часу. При першому способі по провіднику в стравохід вводили доставковий пристрій (пластикова трубка із зовнішнім діаметром 5-7 мм), в якому в стислому стані містився стент, і під рентгеноскопічним контролем пристрій просували до необхідного рівня. Після цього доставковий пристрій витягували, а стент залишався в просвіті органа (завдяки використанню нерухомого штовхача, що знаходився всередині пристрою) і розправлявся. При другому способі по провіднику в стравохід вводили доставковий пристрій, в якому містився замість стента поліуретановий стравохідний буж, - загостреним кінцем вперед. Такий підхід дозволяв безпечно, без загрози перфорації стінки стравоходу (завдяки направляючій провідника) розбужувати стриктуру, подолати іiі вигини і провести крізь неї доставковий пристрій, що був надітий на буж. Після цього буж витягували, а замість нього в ротовий кінець доставкового пристрою вводили стент у стислому стані. Використовуючи штовхач, стент проводили через весь доставковий пристрій до потрібного рівня, після чого доставковий пристрій витягували (як при першому способі). Після завершення процедури стентування хворі зазвичай знов приймали рентгеноконтрастну суспензію, що дозволяло контролювати якість процедури - розширення звуженої ділянки стравоходу, відсутність попадання суспензії у норицю при іiі наявності та задовільний пасаж рентгеноконтрастної речовини по стравоходу у шлунок.

Субопераційну постановку стентів використовували в ході оперативних втручань, при яких констатували неможливість видалення пухлини. Стенти також встановлювали через рот, використовуючи струну-провідник і доставковий пристрій. Положення стента в момент його розправлення контролювали мануально, обмацуючи стравохід вище і нижче пухлини.

\section{РЕЗУЛЬТАТИ}

Безпосередні результати лікування. У групі хворих на РВВС, що були стентовані після встановлення діагнозу та дообстеження (10 хворих), 6 пацієнтам було виконане тільки стентування, 4 хворим після стентування вдалося провести паліативне лікування, з яких 2 хворим проведено курс ПТ, 1 - курс системної ПХТ та ще 1 - курс РХТ із застосуванням селективної ПХТ.

35 хворих на РВВС, у яких після встановлення діагнозу та дообстеження було діагностовано стравохідні нориці, у 2 було виконане тільки стентування, а 3 хворим після стентування надалі проведена паліативна терапія: в 1 випадку - курс ПТ, у 2 РХТ (в одному випадку - ПХТ, у другому - селективна ПХТ).

Із 5 хворих на РВВС, які були стентовані після курсу ПТ, подальше спеціальне лікування не було проведене у жодному випадку. Також надалі терапію не призначали в обох випадках стентування хворих після РХТ із застосуванням системної ПХТ. У Хворих, стентованих після РХТ із застосуванням селективної ПХТ, подальше лікування вдалося продовжити у 4 випадках, 3 яких у 2 було проведено додатковий курс паліативної ПТ, в 1 - РХТ із застосуванням системної ПХТ та ще в 1 - паліативну системну ПХТ. 
Із 2 хворих зі встановленими стентами після селективної ПХТ в одному випадку додатково проведено курс ПТ, а у другому - PXТ із застосуванням системної ПХТ.

Із хворих на РВВС, у яких виникли стравохідні нориці на тлі лікування, 2 пацієнтам вдалося продовжити паліативну терапію після стентування. В одному випадку після селективної ПХТ та подальшого стентування була проведена системна ПХТ, у другому після РХТ із застосуванням селективної ПХТ також системна ПХТ, причому стент у цього хворого у подальшому був видалений. Треба зазначити, що в одного хворого після РХТ із застосуванням селективної ПХТ стентування з приводу нориці було виконане тричі, а у іншого, якому була проведена системна ПХТ та встановлений стент з приводу нориці, що виникла на тлі лікування, проведений ще один курс системної ПХТ, але це зумовило виникнення ще однієї нориці, тому, відповідно, був встановлений ще один стент.

У 14 з 24 хворих на РСЧВВС після встановлення діагнозу та дообстеження було виконане лише стентування, подальша терапія не проводилася у зв'язку з конкуруючою супутньою патологією, станом хворих або занедбаністю основного процесу. Іншим 10 хворим після стентування була проведена спеціальна терапія, а саме: 5 хворим - курс паліативної ПТ, 2 - курс системної ПХТ та 3 - курс РХТ (у 2 випадках із застосуванням системної ПХТ, в 1 - селективної).

У 12 з 15 хворих на РСЧВВС, що були стентовані з приводу нориць без попередньої терапії, було виконане лише стентування. У 3 хворих проведена подальша паліативна терапія: у одному випадку - курс ПТ, в другому - системна ПХТ та в третьому випадку - РХТ із застосуванням системної ПХТ

У 16 хворих на РСЧВВС стентування було виконане після проведення ПТ, з яких у 4 пацієнтів надалі застосовано ще один курс ПТ, а ще у 4 - ПХТ ( 3 - селективна ПХТ, 1 - системна).

1 хворий був стентований після проведення системної ПХТ, причому стентування було виконане двічі. Із 3 хворих, що були стентовані після проведення селективної ПХТ, в 1 проведено курс ПТ, а ще в 1 - селективної ПХТ.

У 6 хворих на РСЧВВС стентування було виконане після PXТ (у 3 - після системної, у 3 - після селективної ПХТ). Ще у 2 хворих після РХТ із застосуванням системної ПХТ проведено подальше лікування після стентування: в одного - селективну ПХТ, у іншого - РХТ із застосуванням селективної ПХТ.

6 хворих на РСЧВВС були стентовані з приводу нориць, що виникли на тлі лікування: 4 - після ПТ, 2 - після РХТ із застосуванням селективної ПХТ. Подальша паліативна терапія у них не проводилася у жодному випадку.

У групі хворих, яким було виконано накладення стоми, у 8 пацієнтів подальша терапія не проводилася. ПТ застосовано у 12 пацієнтів, ПХТ - у 4 та РХТ - у 29.

3 наведених даних випливає, що стентування хворих як на РВВС, так і на РСЧВВС у деяких випадках дає змогу проводити паліативну терапію після відновлення задовільного нутритивного статусу пацієнтів. До того ж, така сама можливість подальшого паліативного лікування з'являється у деяких хворих після стентування з приводу стравохідних нориць. Треба зазначити, що подібна терапія стає доступною і в багатьох хворих на РС після накладення стоми, але, як ішлося вище, стома не накладається за наявності стравохідної нориці.

Важливим $є$ те, що стентування під час та після проведеного лікування у деяких випадках дозволяє продовжити подальшу паліативну терапію після відновлення задовільного нутритивного статусу пацієнтів. Стентування дає також можливість усунути ускладнення лікування, пов'язані з виникненням стравохідних нориць на тлі терапії. Але привертає увагу той факт, що продовжити лікування після стентування з приводу нориць, що розвинулися на тлі лікування, вдалося у 2 з 6 хворих на РВВС на відміну від 6 пацієнтів із РСЧВВС.

Віддалені результати лікування. У табл. 1 та на рис. 1 наведено виживаність хворих після стентування в основній і порівняльній групах залежно від локалізації первинної пухлини.
Таблиця 1. Виживаність хворих після стентування у основній та порівняльній групах залежно від локалізації первинної пухлини

\begin{tabular}{ccc}
\hline Часові & \multicolumn{2}{c}{ Виживаність, \% } \\
\cline { 2 - 3 } інтервали, міс & PBBC (n=49) & PCчBBC (n=73) \\
\hline 3 & $83,33 \pm 5,38$ & $76,81 \pm 5,08$ \\
6 & $60,13 \pm 7,10$ & $44,62 \pm 6,01$ \\
9 & $40,45 \pm 7,19$ & $31,24 \pm 5,62$ \\
12 & $26,97 \pm 6,57$ & $22,31 \pm 5,06$ \\
15 & $15,73 \pm 5,42$ & $14,87 \pm 4,33$ \\
18 & $13,48 \pm 5,09$ & $8,92 \pm 3,47$ \\
21 & $6,74 \pm 3,75$ & $4,06 \pm 2,47$ \\
24 & $5,62 \pm 3,45$ & $3,04 \pm 2,23$ \\
27 & $3,75 \pm 2,76$ & $2,28 \pm 1,91$ \\
30 & $1,87 \pm 1,91$ & $1,14 \pm 1,25$ \\
33 & $0,94 \pm 1,34$ & $0,57 \pm 0,85$ \\
\hline
\end{tabular}

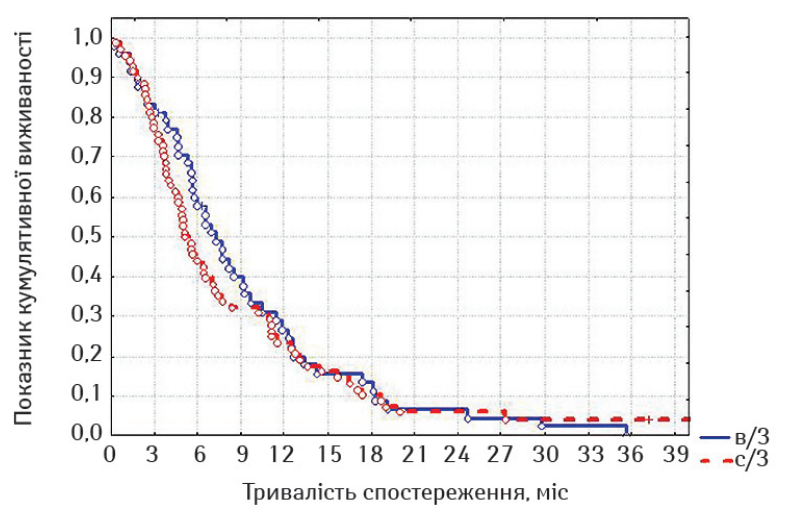

Рис. 1. Виживаність хворих після стентування у основній та порівняльній групах залежно від локалізації первинної пухлини за Капланом - Мейєром: в/3 - хворі на РВВС; с/3 - хворі на РСЧВВС

Як можна бачити 3 наведених табл. 1 та рис. 1 даних, $€$ тенденція до кращої виживаності після стентування у хворих на РВВС, ніж у хворих на РСЧВВС, у всі місяці спостереження, але при вивченні лог-рангових критеріїв ( $\mathrm{p}=0,59023, \mathrm{p}>0,05)$ статистичні розбіжності недостовірні.

На рис. 2 та 3 наведено оцінки ризику миттєвої смерті у хворих на РВВС та РСЧВВС за методом найменших квадратів.

За даними рис. 2, у хворих на РВВС ризик смерті є достатньо високим, він зростає протягом 1-го року спостереження, на 15-му місяці спостереження відмічається його короткочасне зниження, але він підвишується до ще більших значень на 18-му місяці, знижуючись знов на 21-му місяці, після чого ризик смерті знов зростає до максимальних значень. Такі розбіжності в різні місяці спостереження ми пояснюємо достатньо різнорідним складом дослідної групи і за поширеністю процесу, і за ускладненнями хвороби та лікування (наявність нориць), і за конкуруючою супутньою патологією, і за загальним станом.

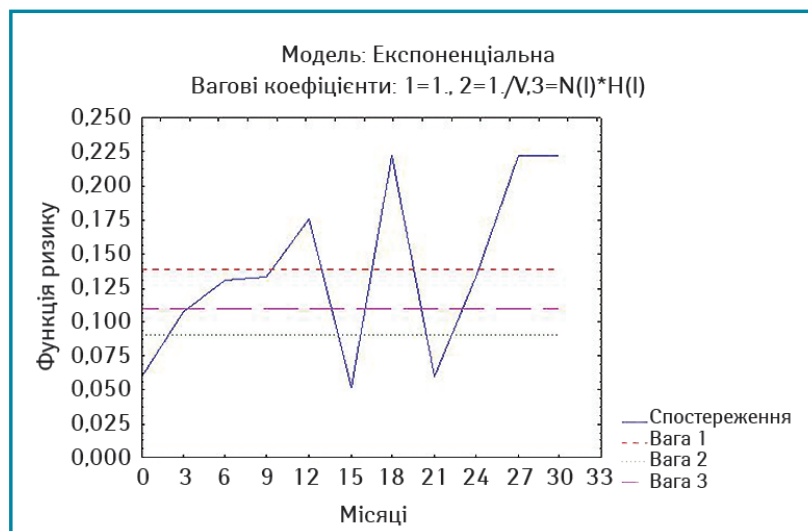

Рис. 2. Оцінка ризику смерті хворих на РВВС після стентування за методом найменших квадратів 


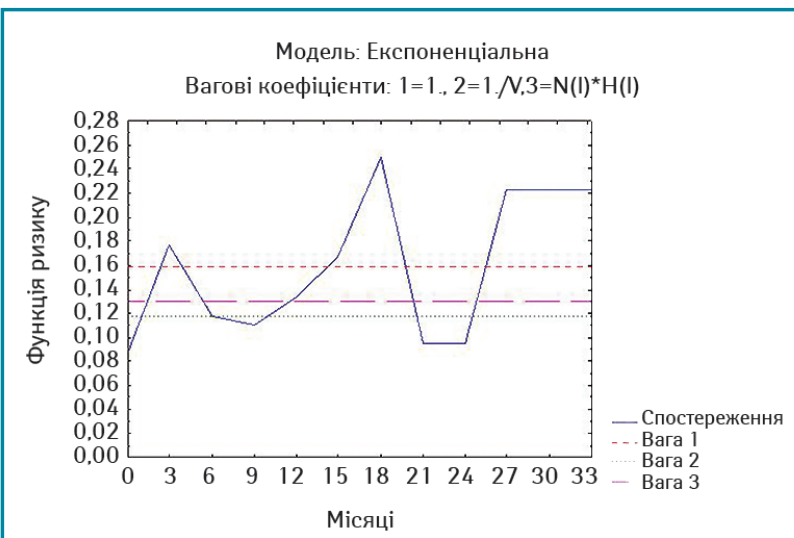

Рис. 3. Оцінки ризику смерті хворих на РСЧВВС після стентування за методом найменших квадратів

Дані рис. 3 свідчать, що у хворих на РСЧВВС після стентування ризик смерті також є достатньо високим, причому вагові прямі є вищими для цих хворих. Однак з 3-го місяця спостереження ризик знижується, істотно зростаючи до 18-го місяця спостереження, але знов знижується наприкінці 2-го року спостереження. Із 3-го року також, як в основній дослідній групі, починається логічне підвищення ризику смерті.

Медіану та середню тривалість життя хворих після стентування в основній та порівняльній групах залежно від локалізації первинної пухлини наведено у табл. 2, з якої також можна побачити, що розбіжності недостовірні.

Таблиця 2. Медіана та середня тривалість життя хворих після стентування в основній та порівняльній групах залежно від локалізації первинної пухлини

\begin{tabular}{|c|c|c|}
\hline $\begin{array}{c}\text { Локалізація } \\
\text { первинної пухлини }\end{array}$ & Медіана життя, міс & $\begin{array}{c}\text { Середня тривалість } \\
\text { життя, міс }\end{array}$ \\
\hline PBBC & 6,74 & $8,96 \pm 0,30$ \\
\hline РСЧВВС & 5,13 & $9,16 \pm 0,36$ \\
\hline Усього & 5,90 & $9,08 \pm 0,20$ \\
\hline
\end{tabular}

Отже, із вищенаведеного випливає, що виживаність хворих після стентування залежно від локалізації пухлини у стравоході достовірно не відрізняється, але простежується тенденція до кращих віддалених результатів у хворих на РВВС, що підтверджують показники медіани та середньої тривалості життя.

Надалі логічним нам здалося проведення порівняння виживаності хворих, що були стентовані з приводу стравохідної нориці та дисфагії без нориці (табл. 3 та рис. 4).

Таблиця 3. Виживаність хворих після стентування у дослідних групах залежно від наявності езофагеальної нориці

\begin{tabular}{ccc}
\hline $\begin{array}{c}\text { Часові } \\
\text { інтервали, міс }\end{array}$ & $\begin{array}{c}\text { Без нориці } \\
(\mathbf{n = 9 0 )}\end{array}$ & $\begin{array}{c}\text { 3 норицею } \\
(\mathbf{n = 3 2})\end{array}$ \\
\hline 6 & $59,04 \pm 5,40$ & $43,33 \pm 9,05$ \\
12 & $34,18 \pm 5,67$ & $26,83 \pm 8,56$ \\
18 & $19,23 \pm 5,30$ & $12,19 \pm 6,90$ \\
24 & $12,82 \pm 5,12$ & $6,09 \pm 5,52$ \\
\hline
\end{tabular}

За наведеними даними стає очевидною краща виживаність хворих, які не мали стравохідної нориці, що підтверджують значення медіани та середньої тривалості життя (табл. 4). Але треба зазначити, що при порівнянні лог-рангових критеріїв розбіжності недостовірні ( $\mathrm{p}=0,16888, \mathrm{p}>0,05)$.

Після встановлення факту кращих результатів виживаності у хворих, яким було проведене стентування не з приводу нориці, ми дослідили окремо виживаність у кожній із груп залежно від наявності нориці (табл. 5, 6, рис. 5-8).

Привертає увагу те, що в групі стентованих хворих на РВВС значно кращою виявилася виживаність осіб з відсутністю стравохідної нориці починаючи з 6-го місяця спостереження, хоча й розбіжність показників лог-рангових критеріїв не є достовірною $(\mathrm{p}=0,16413, \mathrm{p}>0,05)$, а у групі стентованих хворих

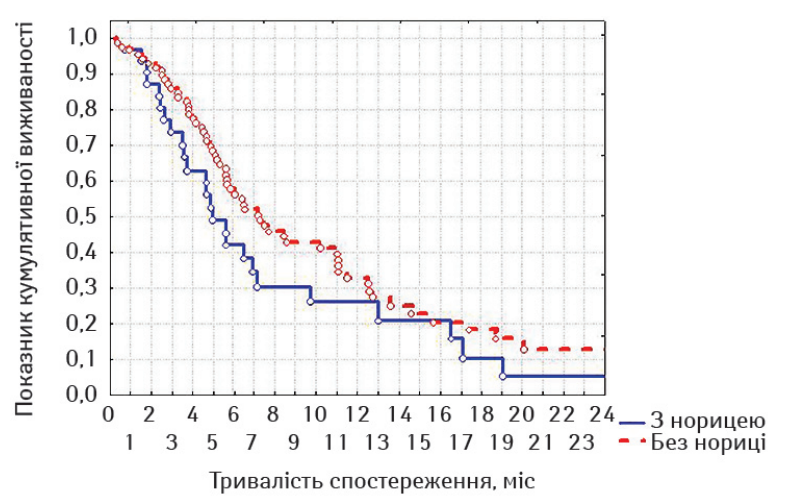

Рис. 4. Виживаність хворих після стентування удослідних групах залежно від наявності стравохідної нориці за Капланом - Мейєром

Таблиця 4. Медіана та середня тривалість житя хворих після стентування у дослідних групах залежно від наявності езофагеальної нориці

\begin{tabular}{ccc}
\hline $\begin{array}{c}\text { Локалізація первинної } \\
\text { пухлини }\end{array}$ & $\begin{array}{c}\text { Медіана } \\
\text { життя, міс }\end{array}$ & $\begin{array}{c}\text { Середня трива- } \\
\text { лість життя, міс }\end{array}$ \\
\hline Без нориці & 5,67 & $9,51 \pm 1,68$ \\
3 норицею & 4,79 & $4,79 \pm 1.29$ \\
\hline
\end{tabular}

Таблиця 5. Виживаність хворих на РВВС після стентування залежно від наявності нориці

\begin{tabular}{ccc}
\hline $\begin{array}{c}\text { Часові } \\
\text { інтервали, міс }\end{array}$ & $\begin{array}{c}\text { Без нориці } \\
(\mathbf{n}=\mathbf{3 8})\end{array}$ & $\begin{array}{c}\text { 3 норицею } \\
(\mathbf{n = 1 1 )}\end{array}$ \\
\hline 3 & $91,43 \pm, 473$ & $89,47 \pm 9,96$ \\
6 & $69,92 \pm 8,49$ & $61,94 \pm 17,60$ \\
9 & $59,93 \pm 9,78$ & $30,97 \pm 17,81$ \\
12 & $56,18 \pm 10,51$ & $15,49 \pm 14,11$ \\
15 & $43,70 \pm 13,71$ & \\
18 & $29,13 \pm 19,14$ & \\
21 & $14,57 \pm 17,43$ & \\
\hline
\end{tabular}

Таблиця 6. Виживаність хворих на РСЧВВС після стентування залежно від наявності нориці

\begin{tabular}{ccc}
\hline $\begin{array}{c}\text { Часові } \\
\text { інтервали, міс }\end{array}$ & $\begin{array}{c}\text { Без нориці } \\
(\mathbf{n = 5 2 )}\end{array}$ & $\begin{array}{c}\mathbf{3} \text { норицею } \\
(\mathbf{n = 2 1 )}\end{array}$ \\
\hline 3 & $82,00 \pm 5,43$ & $66,67 \pm 10,28$ \\
6 & $49,60 \pm 7,10$ & $33,33 \pm 10,28$ \\
9 & $33,07 \pm 6,72$ & $28,21 \pm 9,90$ \\
12 & $20,67 \pm 5,80$ & $25,38 \pm 9,68$ \\
15 & $12,40 \pm 4,73$ & $20,31 \pm 8,98$ \\
21 & $8,27 \pm 3,96$ & $10,15 \pm 6.78$ \\
\hline
\end{tabular}

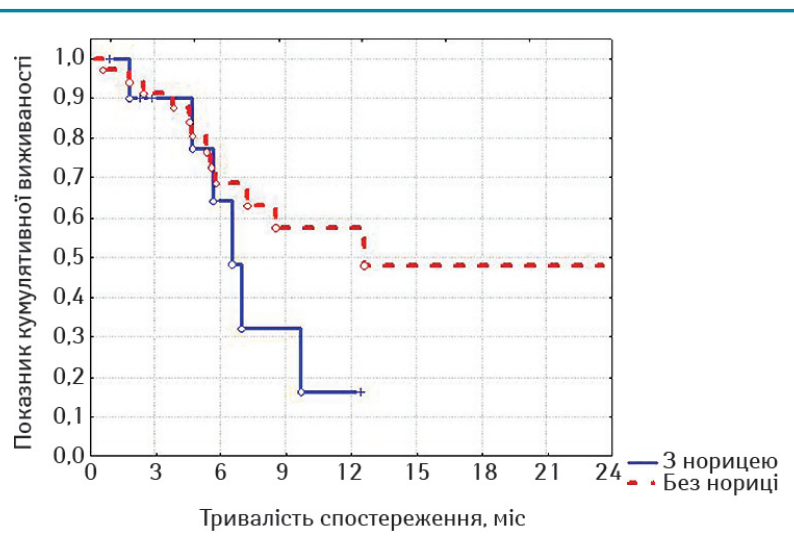

Рис. 5. Виживаність хворихна РВВС після стентування залежно від наявності стравохідної нориці за Капланом - Мейєром

на РСЧВВС залежно від наявності нориці показники виживаності суттєво не відрізнялися ( $\mathrm{p}=0,53077, \mathrm{p}>0,05)$. Відповідно, була порівняна виживаність залежно від наявності або відсутності стравохідної нориці між дослідними групами; значення виявилися достатньо показовими. 
3 наведених даних випливає, що при відсутності стравохідної нориці виживаність стентованих хворих на РВВС була достовірно кращою, ніж хворих на РСЧВВС (при вивченні лог-рангових критеріїв $\mathrm{p}=0,01351, \mathrm{p}<0,05)$, а за наявності нориці виживаність між групами достовірно не відрізнялася $(\mathrm{p}=0,56433, \mathrm{p}>0,05)$. Отже, найкращими віддалені результати лікування після стентування виявилися у хворих на РВВС, що не мали стравохідної нориці.

Для більш детальної оцінки результатів лікування ми визначили ризики миттєвої смерті за методом найменших квадратів окремо у хворих на РВВС та РСЧВВС, що були стентовані не з приводу нориць, та у хворих обох дослідних груп із встановленими стентами з приводу нориць (рис. 9-11).

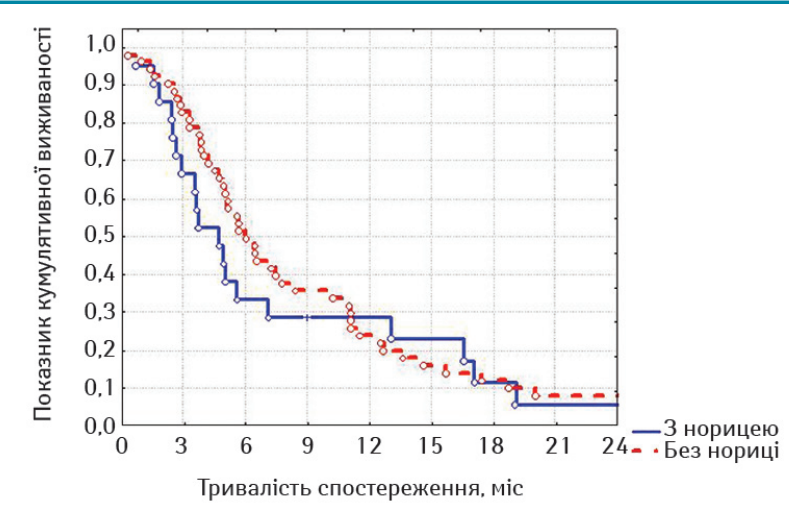

Рис. 6. Виживаність хворих на РСЧВВС після стентування залежно від наявності нориці за Капланом - Мейєром

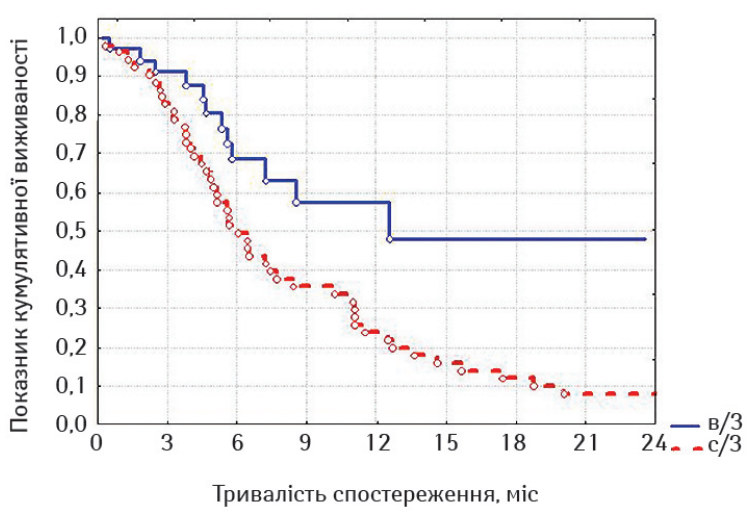

Рис. 7. Виживаність хворих, що не мали стравохідної нориці, у дослідних групах після стентування за Капланом Мейєром: в/3 - хворі на РВВС; с/3 - хворі на РСЧВВС

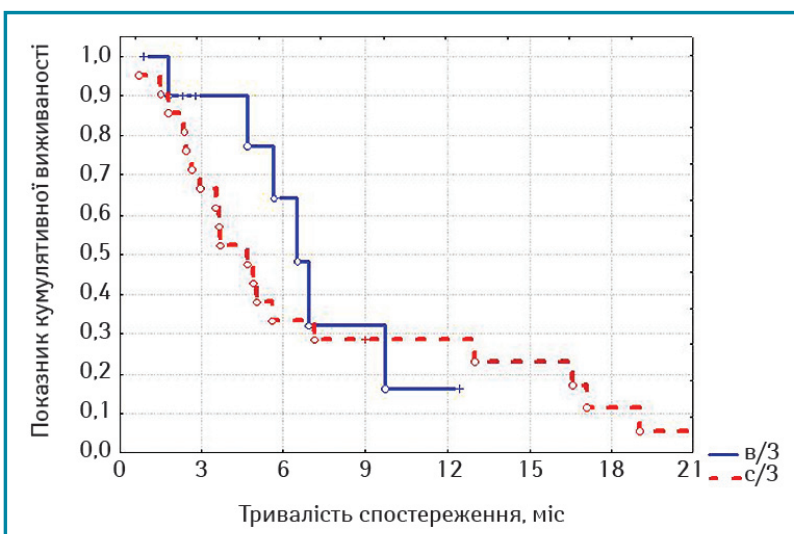

Рис. 8. Виживаність хворих, що мали стравохідні нориці, у дослідних групах після стентування за Капланом - Мейєром: в/3 - хворі на РВВС; с/3 - хворі на РСЧВВС
Оцінка ризиків миттєвої смерті є тотожною визначенню hazard ratio.

Як свідчать дані наведених рисунків, найнижчий ризик миттєвої смерті мають стентовані хворі на РВВС (без нориць), у яких тільки на 3-му місяці спостереження ризик зростає вище значень двох вагових коефіцієнтів та повторно починає зростати після 9-го місяця спостереження (див. рис. 9). У стентованих хворих на РСЧВВС з відсутністю нориць починаючи з 3-го місяця спостереження ризик смерті є вищим за значення двох вагових коефіцієнтів та надалі зростає після 15-го місяця спостереження (див. рис. 10). У стентованих хворих на РС з приводу нориць ризик смерті $є$ також високим на 3-му місяці спостереження та зростає через рік спостереження (див. рис. 11).

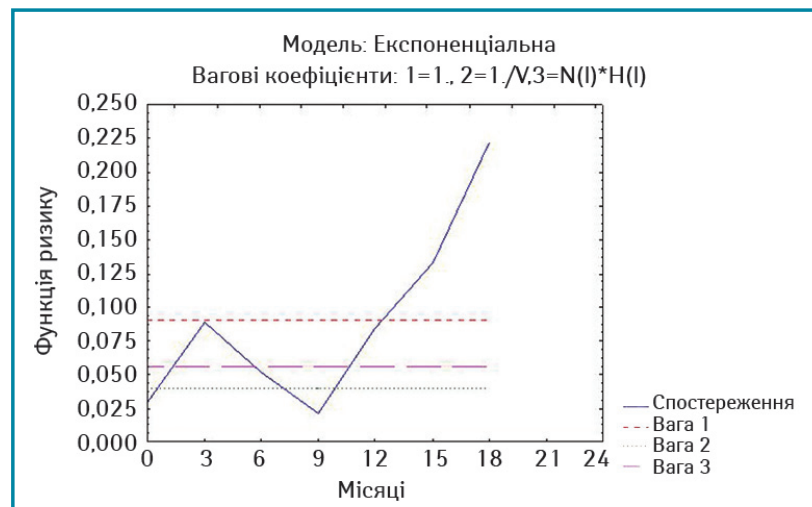

Рис. 9. Оцінка ризику смерті хворих на РВВС після стентування не з приводу стравохідних нориць методом найменших квадратів

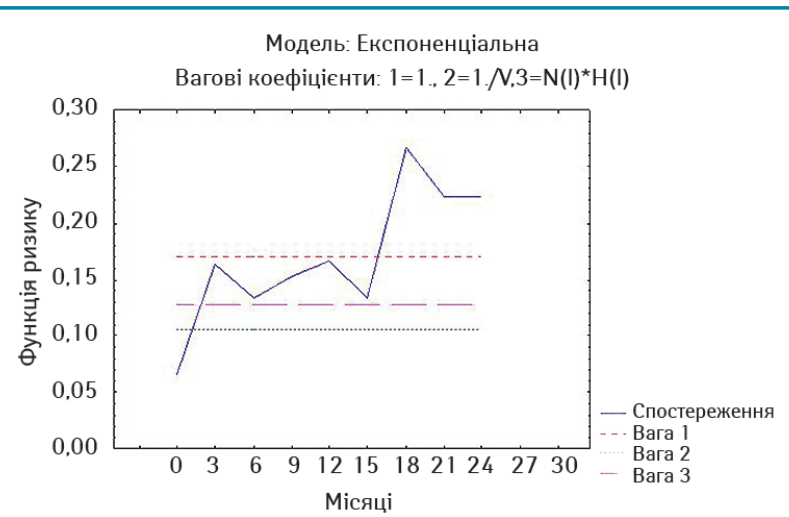

Рис. 10. Оцінка ризику смерті хворих на РСЧВВС після стентування не з приводу стравохідних нориць за методом найменших квадратів

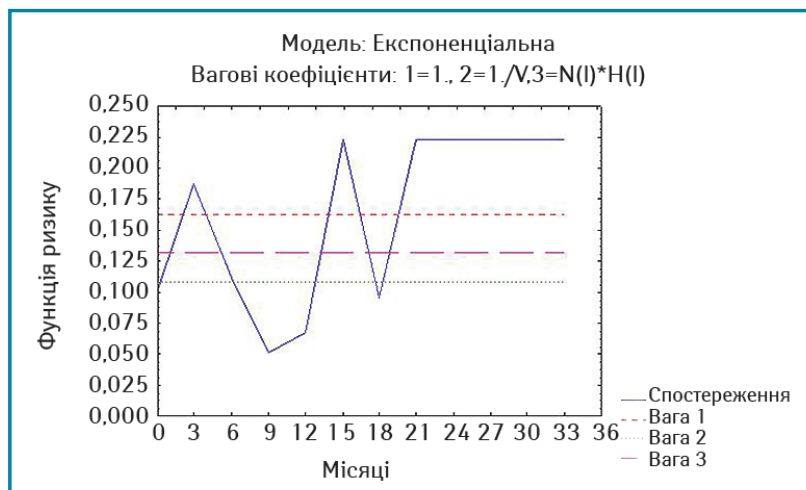

Рис. 11. Оцінка ризику смерті хворих на РС після стентування з приводу стравохідних нориць за метод найменших квадратів 
Ми порівняли віддалені результати після стентування хворих із зазначеними локалізаціями із результатами виживаності хворих на РС після накладення стоми (табл. 8, рис. 12).

При оцінці лог-рангових критеріїв виявлено, що хворі на РС достовірно краще жили після накладення стоми, на відміну від пацієнтів з проведеним стентуванням на всіх строках спостереження $(\mathrm{p}=0,00296, \mathrm{p}<0,05)$. Отримані дані не виявилися для нас несподіванкою, тому що у групу стентованих увійшли хворі зі стравохідними норицями, тоді як з цим ускладненням у групі зі стомами таких хворих не було.

Оцінено ризики миттєвої смерті хворих після накладення стоми за методом найменших квадратів (рис. 13). Судячи з рис. 13, можна казати про істотний високий ризик смерті хворих на РС після накладення стоми на 6, 12-й та 21-й місяць спостереження та мінімальний ризик на 15-й та 3 24-го по 30-й місяць спостереження з його логічним зростанням надалі.

Виходячи з того, що накладення стоми при РС виконували у хворих, що не мали стравохідної нориці, ми порівняли віддалені результати стентування у дослідних групах з результатами

Таблиця 8. Виживаність хворих на РС після накладення стоми та стентування

\begin{tabular}{ccc}
\hline $\begin{array}{c}\text { Часові } \\
\text { інтервали, міс }\end{array}$ & $\begin{array}{c}\text { Накладення стоми } \\
(\mathbf{n}=\mathbf{1 2 2})\end{array}$ & $\begin{array}{c}\text { Стентування } \\
(\mathbf{n}=\mathbf{5 3})\end{array}$ \\
\hline 3 & $92,38 \pm 3,66$ & $73,33 \pm 8,07$ \\
6 & $74,88 \pm 6,03$ & $41,14 \pm 9,23$ \\
9 & $50,59 \pm 7,06$ & $29,38 \pm 8,74$ \\
12 & $42,16 \pm 7,03$ & $25,19 \pm 8,44$ \\
15 & $27,03 \pm 6,42$ & $20,61 \pm 8,05$ \\
18 & $24,77 \pm 6,27$ & $10,30 \pm 6,54$ \\
21 & $19,82 \pm 5,92$ & $7,73 \pm 5,83$ \\
\hline
\end{tabular}

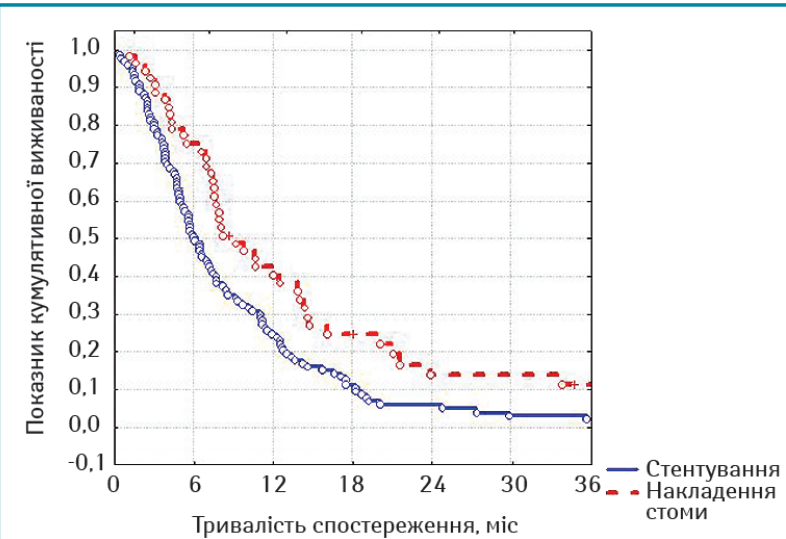

Рис. 12. Виживаність хворих після стентування та накладення стоми: стентування - хворі на РС, яким виконане стентування; накладення стоми - хворі на РС, яким накладено стому

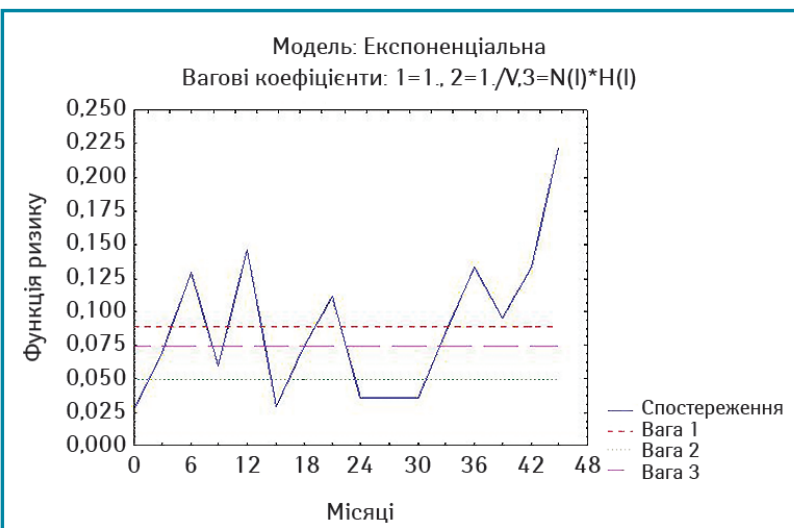

Рис. 13. Оцінка ризику смерті хворих на РС після накладення стоми методом найменших квадратів накладення стоми, причому у порівняння увійшли пацієнти, у яких стравохідна нориця була відсутня (рис. 14).

При оцінці розбіжностей виявлено, що $\chi^{2}=8,214193$, $\mathrm{p}=0,01646$ ( $<<0,05)$, отже, розбіжності достовірні. При порівнянні лог-рангових критеріїв між окремими групами можна стверджувати, що виживаність стентованих хворих на РСЧВВС не з приводу стравохідної нориці була достовірно гіршою, ніж у таких самих хворих на РВВС ( $p=0,01289$, тобто $\mathrm{p}<0,05)$ та РС після накладення стоми ( $p=0,04984, p<0,05)$. Але при порівнянні виживаності стентованих хворих на РВВС з хворими на РС після накладення стоми статистичні розбіжності недостовірні ( $p=0,44127, \mathrm{p}>0,05)$, але помітно, що у групі хворих на РВВС спостерігається тенденція до кращих віддалених результатів лікування. Відповідно, на основі отриманих даних можна стверджувати, що краща виживаність відмічається у хворих на РВВС, що були стентовані, проти пацієнтів, яким було накладено стому. Таким чином, із наведених даних видно, що стентування хворих на неоперабельний РВВС, не ускладнений стравохідною норицею, $є$ ефективною альтернативою накладенню нутритивної стоми при зазначеній патології, але стентування при РСЧВВС не покрашує віддалені результати лікування порівняно з накладенням стоми.

\section{ВИСНОВКИ}

На основі отриманих результатів досліджень можна стверджувати наступне.

1. Стентування неоперабельних хворих на РВВС та РСЧВВС є виправданим, воно дозволяє пацієнтам продовжити харчування природним шляхом та тим самим значно покращує їхню якість життя, на відміну від накладення стоми.

2. Як стентування, так і накладення стоми при нормалізації нутритивного статусу пацієнтів та відсутності протипоказань дозволяють проводити подальшу паліативну терапію.

3. На відміну від накладення стоми, стентування є ефективною методикою усунення стравохідних нориць та подекуди дозволяє проводити паліативне лікування у цього вкрай важкого контингенту хворих з метою продовження тривалості життя. Привертає увагу те, що у первинних хворих, стентованих з приводу нориці, подальшу паліативну терапію вдалося провести лише у 2 випадках РВВС, тоді як у подібних хворих на РСЧВВС подальше лікування застосувати не було можливості.

4. Важливим спостереженням є той факт, що хворі на РВВС, що були стентовані не з приводу нориць, мали достовірно кращі віддалені результати виживаності, ніж пацієнти із РС після накладення стоми та подібні хворі на РСЧВВС. До того ж, виживаність хворих на РВВС після стентування не з приводу нориць була значно кращою, ніж за їх наявності, хоча логрангові розбіжності виявилися недостовірними. Усе це свідчить про високу ефективність стентування хворих на РВВС не з приводу нориць. Важливим також є той факт, що хворі на РСЧВВС,

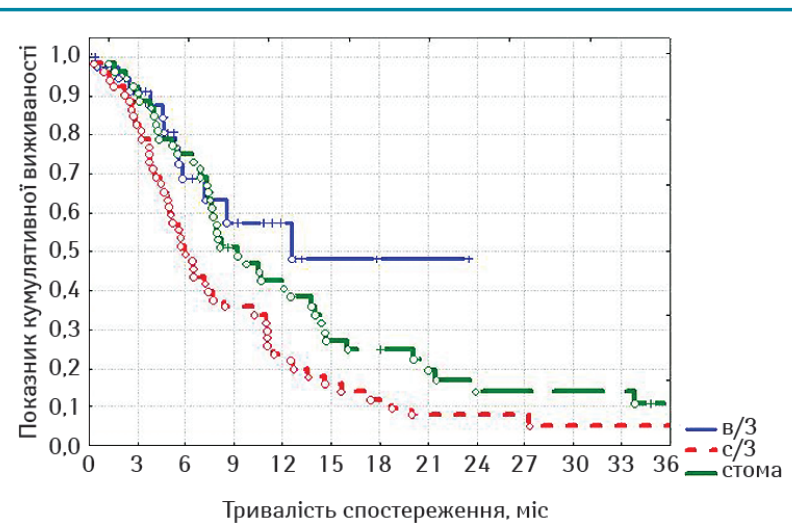

Рис. 14. Виживаність хворих після стентування не з приводу стравохідної нориці та накладення стоми: в/3 - стентовані хворі на РВВС; с/3 - стентовані хворі на РСЧВВС; стома - хворі на РС, яким накладено стому 
що були стентовані з приводу нориць, мали такі самі віддалені результати виживаності, як і хворі на РСЧВВС, що були стентовані не з приводу нориць, що наводить високу ефективність стентування хворих на РСЧВВС з приводу нориць.

\section{СПИСОК ВИКОРИСТАНОЇ ЛІТЕРАТУРИ}

1. Ганул, В. Л., \& Киркилевский, С. И. (2003). Рак пищевода. Руководство для хирургов и онкологов. Киев: Книга плюс.

2. Давыдов, М. И., \& Стилиди, И. С. (2007). Рак пищевода. Москва: Практиеская медицина.

3. Мирошников, Б. И., \& Лебединский К. М. (2002). Хирургия рака пищевода. СПб.: Фолиант

4. Чиссов, В. И., Старинский, В. В., \& Петрова, Г. В. (2008). Онкология. Национальное руководство. Москва: ГЭОТАР-Медиа.

5. Sundelöf, M., Lagergren, J., \& Ye, W. (2008) Surgical factors influencing outcomes in patients resected for cancer of the esophagus or gastric cardia. World Journal of Surgery, 32(11), 2357-2365. doi: 10.1007/s00268-008-9698-2.

6. Xinopoulos, D., Dimitroulopoulos, D., Tsamakidis, K., Korkolis, D., Fotopoulou, A., Bazinis, A., ... Paraskevas E. (2005). Palliative treatment of advanced esophageal cancer with metal-covered expandable stents. A cost-effectiveness and quality of life study. Journal BUON, 10(4), 523-528.

7. Киркилевский, С. И., Ганул, В. Л., Козачук, А. М., Лукашенко, А. В., Кондрацкий Ю. Н., Крахмалев, П. С., ... Зайцев, С. Л. (2007). Стентирование пищевода. Журнал НАМН України, 13(4), 700-716.

8. Соколов, В. В. (2007). Эндопротезирование при злокачественной стриктуре пищевода и кардии. Клинические технологии, 1, 16

9. Ross, W. A., Alkassab, F., Lynch, P. M., Ayers, G. D., Ajani, J., Lee, J. H., \& Bismar, M. (2007). Evolving role of self-expanding metal stents in the treatment of malignant dysphagia and fistulas. Gastrointestinal Endoscopy, 65, 70-76. doi: 10.1016/j.gie.2006.04.040.

10. Siersema, P. D., Dees, J., \& van Blankenstein, M. (1998). Palliation of malignant dysphagia from oesophageal cancer. Rotterdam Oesophageal Tumor Study Group. Scand J Gastroenterol Suppl Scandinavian Journal of Gastroenterology, 225, 75-84.

11. Siersema, P. D., Homs, M. Y., Haringsma, J., Tilanus, H. W., \& Kuipers, E. J. (2003). Use of large-diameter metallic stents to seal traumatic nonmalignant perforations of the esophagus. Gastrointestinal Endoscopy, 58(3), 356-361.

12. Малихова, О. А., \& Поддубный, Б. К. (2008). Эндоскопическое стентирование органов желудочно-кишечного тракта при опухолевых и рубцово-воспалительных стенозах. Тихоокеанский медицинский журнал, 4 (прилож.), 80-83.

13. Муравьев, В. Ю., Иванов, А. И., Сигал, Е. И., Бурмистров, М. В., Попов, В. А., Сигал, А. М., ... Максимов, А. П. (2017). Опыт лечения несостоятельностей пищеводных анастомозов и послеоперационной перфорации пищевода с использованием эндоскопических технологий. Поволжский онкологический вестник, 5 (32), 4-12.

14. Austin, A. S., Khan, Z., Cole, A. T., \& Freeman, J. G. (2001). Placement of esophageal self-expanding metallic stents without fluoroscopy. Gastrointestinal Endoscopy, 54(3), 357-359.

15. Rathore, O. I.,Coss, A., Patchett, S. E., \& Mulcahy, H. E. (2006). Direct-vision stenting: the way forward for malignant oesophageal obstruction. Endoscopy, 38(4) 382-384. doi: 10.1055/s-2005-921040.

16. White, R. E., Chepkwony, R., Mwachiro, M., Burgert, S. L., Enders, F. T., \& Topazian M. (2015). Randomized trial of small-diameter versus large-diameter esophagea stents for palliation of malignant esophageal obstruction. Journal of Clinical Gastroenterology, 49(8), 660-665. doi: 10.1097/MCG.0000000000000333.

17. Бурдюков, М. С., Юричев И. Н., \& Нечипай А. М. (2009). Стентирование стенотических стриктур верхних отделов желудочно-кишечного тракта. Сб. тез 13-го Моск. междунар. конгр. по эндоскоп. хирургии, 22-24 апреля 2009 г., 63-64.

18. Годжелло, Э. А., Хрусталёва, М. В., Галлингер, Ю. И., \& Пермяков, В. Б. (2012) Эндоскопическая коррекция позднихосложнений стентирования саморасправляющи мися эндопротезами при бластоматозныхпораженияхпищевода, кардии и пищеводныханастомозов. Альманах института хирургии им. А. В. Вишневского, 7(1), 158-159.

\section{Результаты стентирования больных раком \\ верхних и средних отделов пищевода}

С.И. Киркилевский, П.С. Крахмалев, Р.И. Фридель

Национальный институт рака, Киев

Резюме. Актуальность. На момент установления диагноза больные раком пищевода (РП) зачастую являются неоперабельными в связи с запущенностью процесса. Продолжительность жизни инкурабельных пациентов с выраженной дисфагией составляет в среднем 90 дней. Радикальное лечение может быть выполнено только у 20-30\% больных с 5-летней выживаемостью в пределах 10,3-35\%. Цель. Исследовать непосредственные и отдаленные результаты стентирования больных РП в зависимости от локализации первичной опухоли. Объект и методы. Проанализирован опыт применения внутрипищеводных саморасширяющихся стентов у больных РП (49 случаев - рак верхних и 73 - средних отделов пищевода) в сравнении с наложением стомы (53 случая). Pезультаты. В результате лечения у всех больных, которые были стентированы, уменьшалась дисфагия, появлялась возможность принимать пищу обычным путем, улучшалось качество жизни, у многих появлялась возможность продолжить терапию. Выявлено, что стентирование неоперабельных больных раком верхних и средних отделов пищевода является оправданным, оно позволяет больным продолжить питаться естественным путем и тем самым значительно улучшает качество жизни, в отличие от наложения стомы. Больные раком верхних отделов пищевода, которые были стентированы не по поводу свищей, имели достоверно лучшие отдаленные результаты выживаемости, чем больные РП после наложения стомы и подобные больные раком средних отделов пищевода, причем выживаемость больных раком верхних отделов пищевода после стентирования не по поводу свищей была значительно лучше, чем при их наличии. Больные раком средних отделов пищевода, которые были стентированы по поводу свищей, имели такие же отдаленные результаты выживаемости, как и больные раком средних отделов пищевода, которые были стентированы не по поводу свищей, что указывает на высокую эффективность стентирования при раке средних отделов пищевода по поводу свищей. Выводы. Стентирование неоперабельных больных раком верхних и средних отделов пищевода является оправданным, оно позволяет пациентам продолжить питание естественным путем и тем самым значительно улучшает качество жизни, в отличие от наложения стомы.

Ключевые слова: рак пищевода; рак верхних отделов пищевода; рак средней доли внутригрудного отдела пищевода; стент; стома; свищ.

The results of stenting patients with upper-third and middle-third esophageal cancer

S.I. Kirkilevsky, P.S. Krahmalyov, R.I. Frydel

National Cancer Institute, Kyiv

Summary. Relevance. At the time of diagnosis patients with esophageal cancer (EC) are often inoperable due to locally advanced process. Life expectancy in case of incurable patient with severe dysphagia comprises 90 days in average. Radical treatment can be performed only in $20-30 \%$ of patients with a 5-year survival rate from 10.3 to $35 \%$. Objective. Assessing short-term and long-term outcomes of stenting patients with EC depending on the localization of the primary tumor. Materials and methods. We analyzed our experience of using intraesophageal self-expanding stents in EC patients. 49 of them had tumor in upper-third of esophagus and 73 patients had middle-third tumors location as compared with those with stoma implantation (53 cases) in EC patients. Results. All patients who were stented had significantly lower grade of dysphagia and could eat in the usual way. It also improved quality of life, and many of such patients had an opportunity to continue treatment. It has been revealed that stenting of inoperable cancer patients of the upper and middle-third EC gives benefit to patients as it allows patients to continue to eat naturally and thereby significantly improves the quality of life in contrast to stoma placement. Patients of the upper esophagus who were not stented because of fistula formation had significantly better long-term survival than EC patients with stoma and similar cancer patients of the middle esophagus, and the survival rate of patients with cancer of the upper esophagus after stenting is not for fistula was significantly better than with their availability. Patients with cancer of the middle esophagus, who experienced stent placement because of fistulae, had the same long-term survival results as cancer patients of the middle part of the esophagus who were not stented because of the fistula. It indicates high efficacy of stenting in cancer of the middle-third esophagus with presence of fistula. Conclusion. Stenting of inoperable cancer patients with upper and middle-third of esophagus shows significant benefit. It allows patients to eat naturally, and thereby significantly improves the quality of life in comparison with stoma placement.

Key words: esophageal cancer; cancer of the upper esophagus; cancer of the middle lobe of the intrathoracic esophagus; stent; stoma; fistula.

Адреса:

Крахмальов Павло Сергійович

03022, Київ, вул. Ломоносова, 33/43

Національний інститут раку

E-mail: ivankrah7@gmail.com

Correspondence:

Krahmalyov Pavlo

33/43 Lomonosova str., Kyiv 03022

National Cancer Institute

E-mail:ivankrah7@gmail.com 